\title{
BÓI LORÁND
}

\section{A közösségi közlekedés regionális keresletének és kínálatának tényezői Debrecen vonzáskörzetében}

Egy regionális térben végzett emberi tevékenység akkor müködik hatékonyan, ha a kiszolgáló infrastruktúra, a kapcsolódó szervezeti rendszer, és a régióra jellemző földrajzi adottságok; demográfiai és gazdasági folyamatok rendszerszintű egyensúlya megteremthető. Az egyensúly fenntartásához pedig arra van szükség, hogy a regionális térben bekövetkező változások az infrastruktúrában, szervezeti rendszerben, valamint az elvégzett emberi tevékenységben is leképeződjenek; lehetőleg folyamatos visszacsatolás mellett. ${ }^{1}$ A közösségi közlekedés szervezésének feladata - a városfejlődési szakaszok nyomán megjelenő új közlekedési igényekből fakadó keresletre reagálva - a megfelelő közösségi közlekedési kínálat biztosítása a közlekedési rendszer infrastrukturális és szolgáltatási oldalának alakításán keresztül. A nyugat-európai országokban már az 1960-as évekre általánossá váló szuburbanizációs mobilitási igényekre a közösségi közlekedés szervezése alágazati integrációra építő megoldásokkal válaszolt. ${ }^{2}$

Jelen tanulmány célja a szuburbanizációra jellemző - mobilitási folyamatokra hatást gyakorló - demográfiai, társadalmi és gazdasági folyamatok húsz évre visszatekintő statisztikai elemzésen alapuló feltárása Hajdú-Bihar megyében és Debrecen elővárosi vonzáskörzetében. További cél a közösségi közlekedés kínálati elemeinek szervezeti, infrastrukturális és szolgáltatási szempontú áttekintése; a menetrendi, hálózati adatok és szabályozási dokumentumok feldolgozásán keresztül. A tanulmány kísérletet tesz a közösségi közlekedés regionális keresleti és kínálati jellemzőinek összevetésére, valamint javaslatok megfogalmazására a feltárt disszonanciák megszüntetése érdekében.

\section{Az elemzés módszerei, területi lehatárolása}

Az elemzésben elsődlegesen vizsgált mutatószámok - az irodalmi ajánlásoknak megfelelően - demográfiai jellegüek, a vizsgált célterület külső és belső

\footnotetext{
${ }^{1}$ Heidemann, Claus: Methodologie der Regionalplanung: Die erste \& einzige erläuterte Bilderfibel der Regionalplanung. Diskussionspap-iere des Instituts für Regionalplanung der Universität Karlsruhe No. 16, Institut für Regionalplanung, Karlsruhe, 1996.

${ }^{2}$ ENYEDI GYÖRGY: A városnövekedés szakaszai - újragondolva. Tér és Társadalom. (2011) 25. évf. 1. sz. 5-19.; ERDÖSI FERENC: A kommunikáció (közlekedés-távközlés) szerepe a terület és településfejlödésben I-II. VÁTI, Bp., 2000.
} 
migrációjával, valamint népesedésével kapcsolatosak. ${ }^{3}$ A szuburbanizációs folyamatok megvilágításához további adalékokkal szolgálnak az életkörülményekkel (lakásépítés, laksürüség, motorizáció) és a gazdasági tevékenységgel kapcsolatos mutatószámok (jövedelem, munkanélküliség).

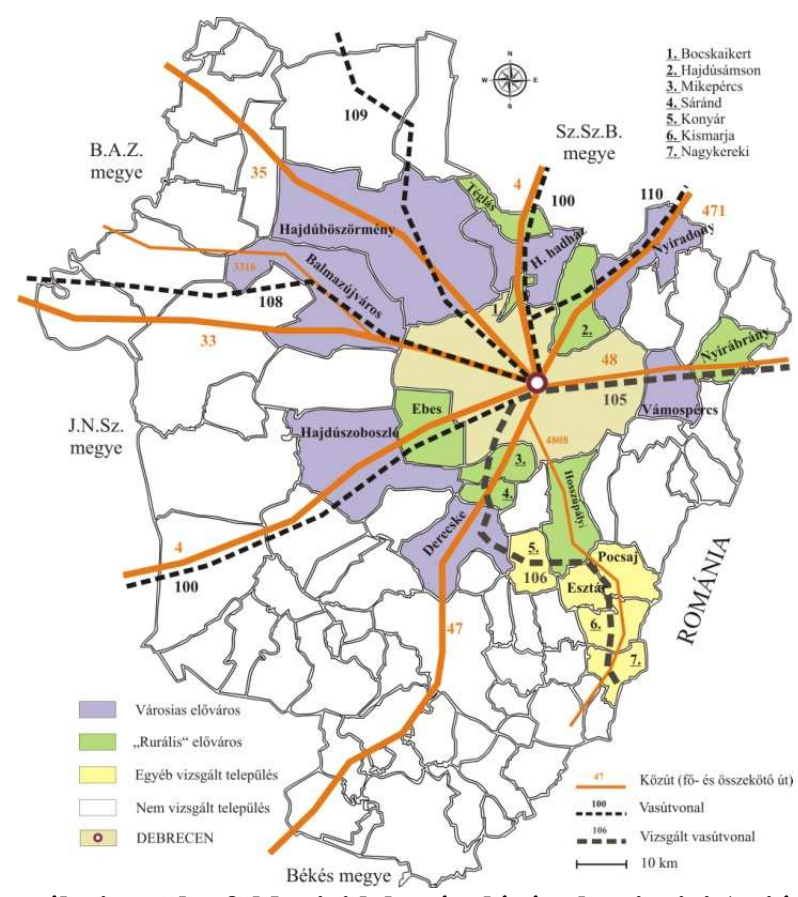

1. ábra. A vizsgálati terület földrajzi lehatárolásának szintjei (saját szerkesztés).

Az egész megyére, valamint a munkanélküliségi rátára vonatkozó általános adatok idősorai a KSH adatforrások rendelkezésre állására való tekintettel eltérő terjedelmüek az 1990-2010-ig terjedő időszakban. A kutatásban vizsgált egyes kiemelt települések (Bocskaikert, Téglás) csak 1993-at követően váltak önállóvá, így a települési migrációval, motorizáltsággal, lakáshelyzettel kapcsolatos információk feldolgozása az 1994 és 2010 közötti évek TeIR-ben szereplő statisztikai adatai alapján történt. A közlekedési szolgáltatásokra is kiterjedő részletes településenkénti idősoros elemzés az 1994-2014 közötti időszakot áttekintve Debrecen, és annak közvetlen elővárosi közösségi közlekedési vonzáskörzetében található további 15 település gyürüje, valamint a 106-os vasútvonal által érintett települések vonatkozásában valósult meg (1. ábra). A keresleti-kínálati folyamatokat mélységeiben feltáró elővárosi elemzésekbe HajdúBihar megyén belüli, a megyeszékhelytől maximálisan $35 \mathrm{~km}$ távolságra található, közösségi közlekedéssel Debrecenből legfeljebb 50 percnyi átlagos utazási idővel közvetlenül elérhető; legalább 15 járatpárral ellátott önálló települések kerültek be.

${ }^{3}$ BAJMÓCY PÉTER: Szuburbanizáció a budapesti agglomeráción kívüli Magyarországon. Doktori (PhD) értekezés. Szegedi Egyetem. Föld-tudományok Doktori Iskola, Szeged, 2003.; VAN DEN BERG, LEO: Urban Europe: A Study of Growth and decline. Oxford. 1999. 
Ezen belül elkülönítettem azokat a városokat, amelyek - korábbi kistérségi, és/vagy jelenlegi járásközponti funkciót ellátva - önmaguk is vonzásközponti szerepet töltenek be a környező települések számára azoktól a településektől, amelyeknek ilyen funkciója nincs. Az első településtípusra az elemzések során a városias elöváros, a másodikra a „rurális” elöváros elnevezést alkalmaztam, bár ez utóbbi kategória esetén a „rurális” jelző a lezajlott szuburbanizációs folyamatok következtében ma már nem minden esetben helytálló.

\section{Regionális keresleti tényezők}

A települések népességváltozását a szakirodalom alapján két fö tényező, a természetes szaporodás/fogyás és vándorlási különbözet befolyásolja. Ezek közül a szuburbanizációs mobilitás szempontjából az irodalmi adatok alapján ez utóbbi az a jellemző mutatószám, melynek vizsgálata támpontokat adhat a Debrecen elővárosában zajló folyamatok pontosabb leírásához. ${ }^{4}$ Hajdú-Bihar megyét a külső migrációs tényezők alapján megvizsgálva megállapítható, hogy a megye külfölddel szembeni vándorlási különbözete többletet mutat. A teljes külső vándorlási különbözet Hajdú-Bihar megye esetén az Észak-alföldi régió megyéinél pozitívabb, ami valószínüleg Debrecen erős iskolavárosi szerepére vezethető vissza. Mindezek ellenére a megye vándorlási különbözete a rendszerváltást követő években az 1994es év kivételével negatív, igaz a veszteség mértéke nem volt túl jelentős (2. ábra). A vizsgált időszakra vonatkozóan megállapítható hogy Hajdú-Bihar megyére a külső migrációs jelenségek nem voltak jellemzők, különösen nem egy németországi, gazdaságilag fejlettebb régióhoz (Karlsruhe) viszonyítva.

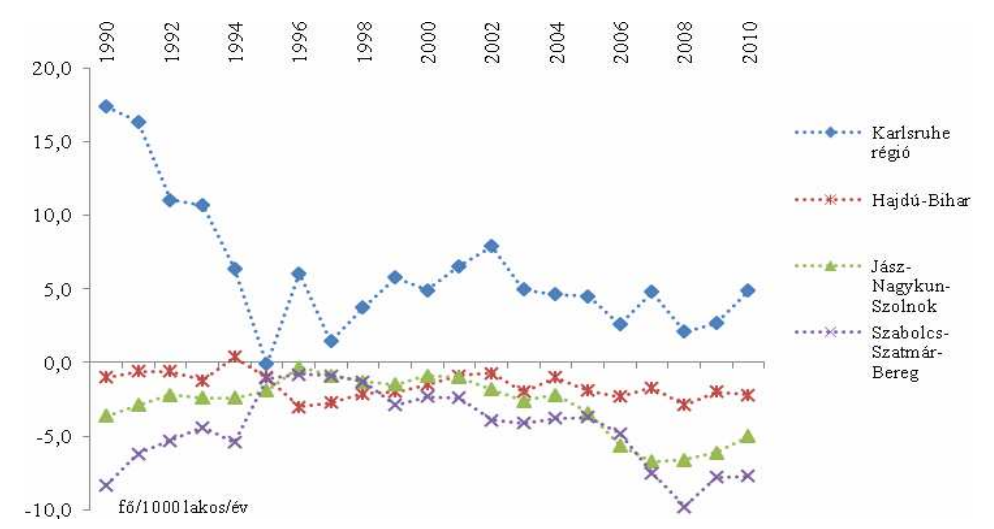

\section{2. ábra. A vándorlási különbözet alakulása regionális összehasonlításban (saját szerkesztés, KSH TeIR alapján).}

Az intraregionális migrációra vonatkozóan a megye 82 települése esetében - az idősoros lakcímnyilvántartási adatokhoz való hozzáférés hiányában - csak az általános vándorlási különbözetre vonatkozóan állt rendelkezésemre információ, a

${ }^{4}$ BAJMÓCY: i. m., 9-15. 
településeknek a megyeszékhellyel szemben számított vándorlási különbözetére vonatkozóan nem. A vándorlási tendenciák 1994 és 2010 közötti - két szakaszra bontott - elemzése alapján azonban így is számos következtetés vonható le (3. ábra). Az első szakaszban (1994-2002) a Debrecen környéki települések esetén intenzív szuburbanizációs jelek mutatkoztak a megyeszékhelyröl történő kiköltözések formájában. A folyamatok legeröteljesebben a Debrecen közvetlen szomszédságában fekvő, kevésbé városias települések (Mikepércs, Bocskaikert, Hajdúsámson) erősen pozitív és Debrecen negatív vándorlási különbözetében érhetők tetten. Kisebb mértékben, de pozitív volt a vándorlási egyenleg a megyeszékhely közvetlen környezetében található városokban (Hajdúböszörmény, Vámospércs, Nyíradony) és a kissé távolabbi, de még Debrecen vonzáskörzetébe tartozó településeken (Létavértes, Tépe, Konyár, Hajdúszovát) is. Megfigyelhető, hogy a kiköltözéssel leginkább érintett települések elsősorban a vasúti és közúti főközlekedési útvonalak által közvetlenül feltárt területeken találhatók. A megye fennmaradó részét néhány kivételtől (Polgár és Zsáka) eltekintve negatív vándorlási egyenleg jellemezte.
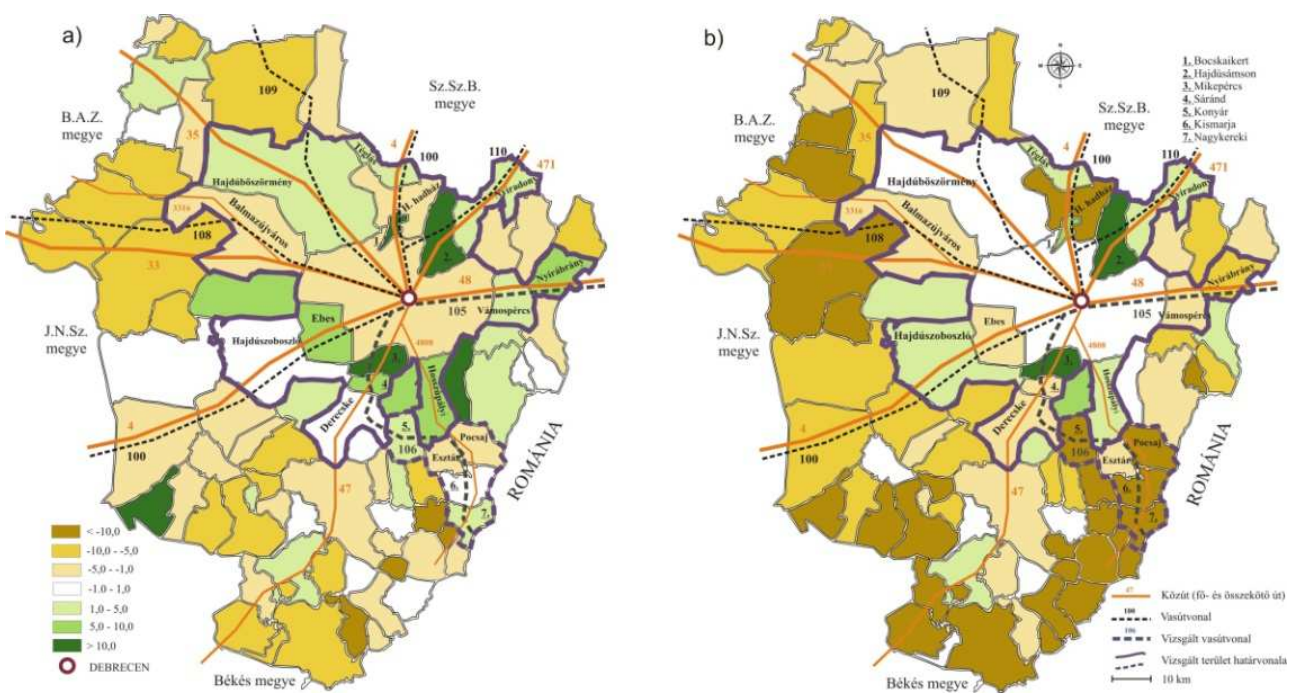

3. ábra. Települések vándorlási különbözetének alakulása 1994-2002 (a), valamint 2002-2010 (b) között Hajdú-Bihar megyében, lakos/1000 fö, (saját szerkesztés KSH, TeIR alapján).

A második szakaszban (2002-2010) a vándorlási adatok elemzése során a korábbitól eltérö tendenciákat figyelhetünk meg. Debrecen éves átlagos vándorlási különbözete pozitívvá változott (0,3 ezrelék), a 2007-es évet követően folyamatosan pozitív értékeket mutatva. Ezzel egyidejüleg a környező kevésbé városias települések pozitív vándorlási különbözete három település (Hajdúsámson, Mikepércs és Hajdúbagos) kivételével csökkent, egyes települések esetében (Ebes, Nyírábrány) negatívvá változott. A Debrecen közvetlen vonzáskörzetében található - korábban vándorlási többlettel rendelkező - városok (Vámospércs, Derecske, Hajdúböszörmény) esetében is negatív, vagy nulla közeli migrációs egyenleg volt tapasztalható. Szintén szembetünő a megye fennmaradó részében megfigyelhető 
elvándorlás, amely különösen az ország, vagy a megyehatár közelében található perifériális településeket jellemezte. Feltételezve, hogy a Debrecen vonzáskörzetében tapasztalható belső migráció hátterében túlnyomó többségben a Debrecen és a környékbeli települések közötti népességmozgás áll; szembetűnő kiköltözési hullám látható a 90-es évektől a 2000-es évek elejéig a centrumvárosból a környező településekre. A 2000-es évek elejétől azonban a folyamat lelassult, a kiköltözés intenzitása és területi kiterjedése csökkenni kezdett a centrumváros népességvonzásának egyidejü növekedése mellett.

A szuburbanizációs folyamatokat alátámasztó jelenségek tapasztalhatók a népsürüségi adatok és a motorizáltság Hajdú-Bihar megyei vizsgálata során is. A népsűrüség - és ezen keresztül a népesség - vizsgált időszakban bekövetkezett változásának elemzésénél szembetűnő, hogy tartós népességnövekedés Hajdú-Bihar megyében kizárólag a „rurális” kategóriába sorolt települések esetében volt megfigyelhető (4. ábra).

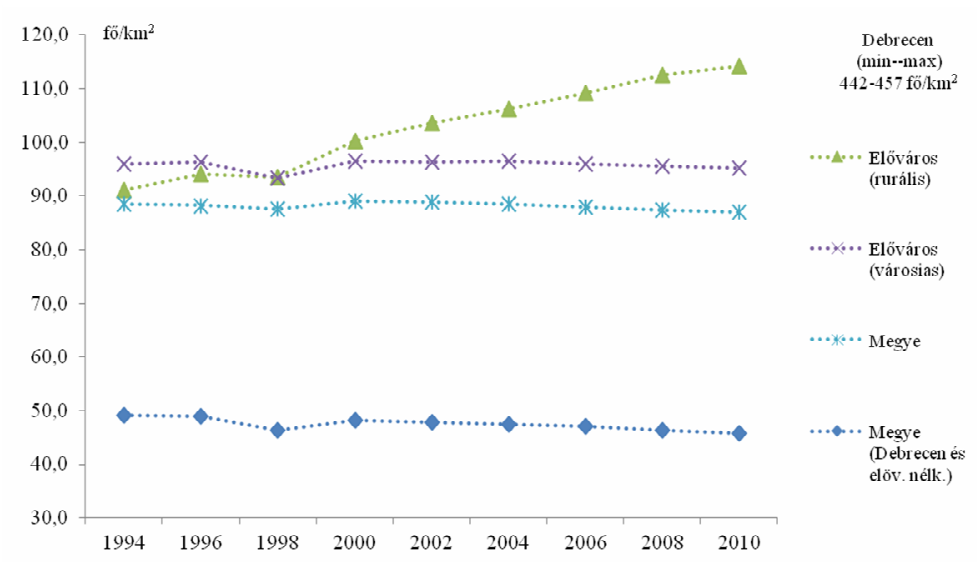

\section{4. ábra. A népsürüség alakulása Hajdú-Bihar megyében 1994-2010, (saját szerkesztés KSH, TeIR alapján).}

A Debrecen elővárosi övezetéhez tartozó városias jellegü településeket a lakosságszám szuburbanizációval kapcsolatos növekedése - eltekintve néhány rövidebb időszaktól - nem érintette jelentős mértékben, az valószínüleg csak a természetes fogyásból eredő népességvesztés kompenzálására volt elegendő. A megye fennmaradó részét a népesség természetes fogyásból és elvándorlásból eredő csökkenése; a megyeszékhelyre, vagy kisebb térségi központi funkciót ellátó városba való beköltözés jellemezte. A motorizáltság szempontjából szintén a „rurális” kategóriába sorolt települések mutatták a legdinamikusabb növekedést, itt az 1000 före jutó személygépkocsik száma a vizsgált időszakban több mint a duplájára nőtt (5. ábra). Jelentős a gyarapodás a Debrecen elővárosán kívül eső területeken is, ami valószínüleg az érintett térségek rosszabb elérhetőségi viszonyaira vezethető vissza. A legmagasabb motorizáltságú megyeszékhelyen 2006-tól, a közepesen motorizált városias elővárosi térségben 2008-tól az 1000 före jutó személygépkocsik száma - a világgazdasági válsággal is összefüggésbe hozható 
- visszaesést mutatott, a megye fennmaradó részében ugyanezen érték változatlan szintje mellett.

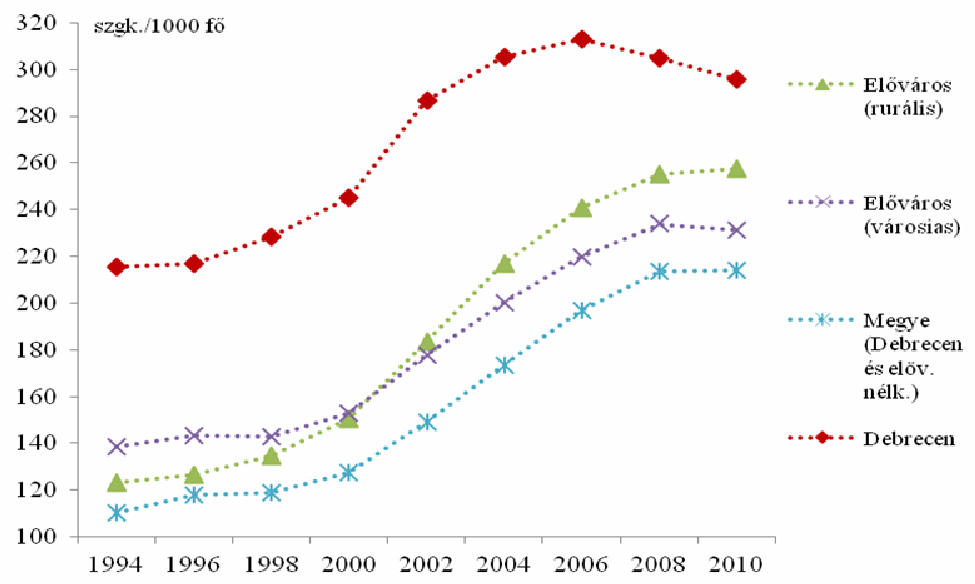

5. ábra. A motorizáltság alakulása Hajdú-Bihar megyében 1994-2010, (saját szerkesztés KSH, TeIR alapján).

A vizsgált terület demográfiai és motorizáltsági adatai alapján a szuburbanizációból eredő közlekedési forgalomnövekedés elsősorban Debrecen és a közvetlen környezetében fekvő kisebb lélekszámú „rurális” kategóriába sorolt alvótelepülések viszonylatában jelentkezett. Ezen felül a Debrecentől távolabb eső települések motorizáltságának növekedése az egyéni közlekedés intenzitásának növekedésére utal az érintett térségek és Debrecen között.

$\mathrm{Az}$ elemzésekhez további adalékkal szolgálnak a lakhatással, lakáskörülményekkel, a munkaerőpiaccal és a jövedelmek alakulásával kapcsolatos mutatószámok is. A lakhatással kapcsolatos adatok közül a szuburbanizáció vonatkozásában leggyakrabban a laksürüség csökkenését említi a szakirodalom, a lakhatási célú területhasználat és a lakott területek egyidejű növekedése mellett. Ezen felül a centrumváros elővárosi zónájában megnövekvő újlakás-építési kedv is a szuburbanizáció kísérőjelenségének számít. ${ }^{5}$

${ }^{5}$ BAJMÓCY: i. m., 9-15. 


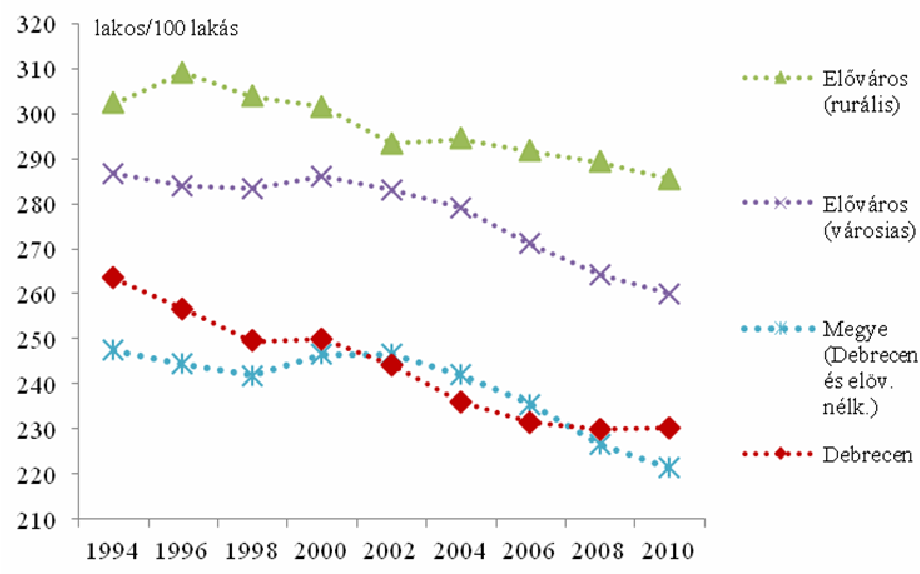

6. ábra. Laksűrüség alakulása Hajdú-Bihar megyében. 1994-2010, (saját szerkesztés KSH, TeIR alapján).

Hajdú-Bihar megye települései esetében a laksürüség csökkenése legerőteljesebben a városias elővárosban és az elővároson kívüli térségeiben jelentkezett. Ennek okai - különösen a megye perifériális területeinél - nem a szuburbanizációban, hanem az egyszemélyes háztartások számának a lakosság elöregedésével kapcsolatos növekedésében keresendők. A városias elővárosi területek és főleg a megyeszékhely esetében a laksürüség csökkenése már jobban összekapcsolható a fiatal családok nagyobb lélekszámú háztartásainak városokból történő kiköltözésével, amely a „,rurális” elővárosi besorolást kapott települések mérsékelt laksürüség csökkenésében is tetten érhető (6. ábra).

Az új lakásépítések és a kiköltözések közötti összefüggéseket vizsgálata alapján kiköltözők által előnyben részesített „rurális” elővárosi települések új lakásépítései egészen a 2008-as gazdasági válságig stabilan követték a népességváltozási folyamatokat. A megyeszékhely és városias elővárosi települések ezzel szemben ingadozó értékeket mutattak. A megye többi részén a 90-es évek végére jellemző „szocpolos”, valamint a 2000-es évek közepén jelentkező hitelbőség miatti lakásépítésektől eltekintve népességarányosan alacsony volt a lakásépítési kedv. 


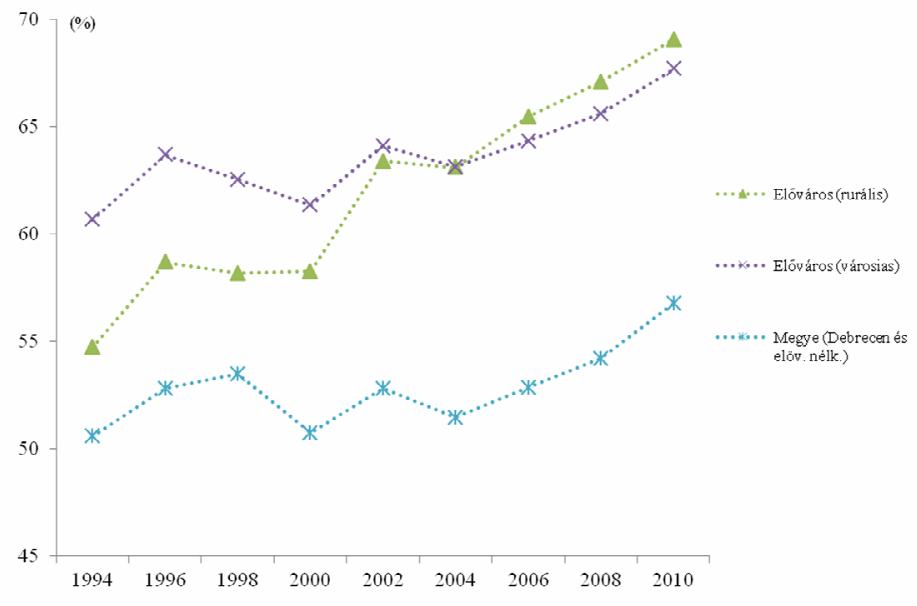

7. ábra. Jövedelemeloszlás alakulása Hajdú-Bihar megyében. 1994-2010, (saját szerkesztés KSH, TeIR alapján).

A jövedelemeloszlás tekintetében az egy före jutó nettó jövedelmek Debrecenhez viszonyított százalékos aránya szintén a „rurális” elővárosi településeknél mutatott átlag feletti növekedést a vizsgált időszakban. Míg a mutató értéke ebben a településkategóriában 1994-ben a megye elővárosi térségen kívüli értékét csak mintegy 4\%-kal meghaladva 54,7\% volt, 2010-re az itt megszerzett jövedelmek aránya a városias előváros területek értékét túllépve a Debrecenben mért szintnek már közel $70 \%$-át tette ki. A vizsgált időszakban a megye fennmaradó területének megyeszékhelyhez viszonyított jövedelme 6\%-kal, a városias elővárosi térségeké pedig 7\%-kal növekedett (7. ábra).

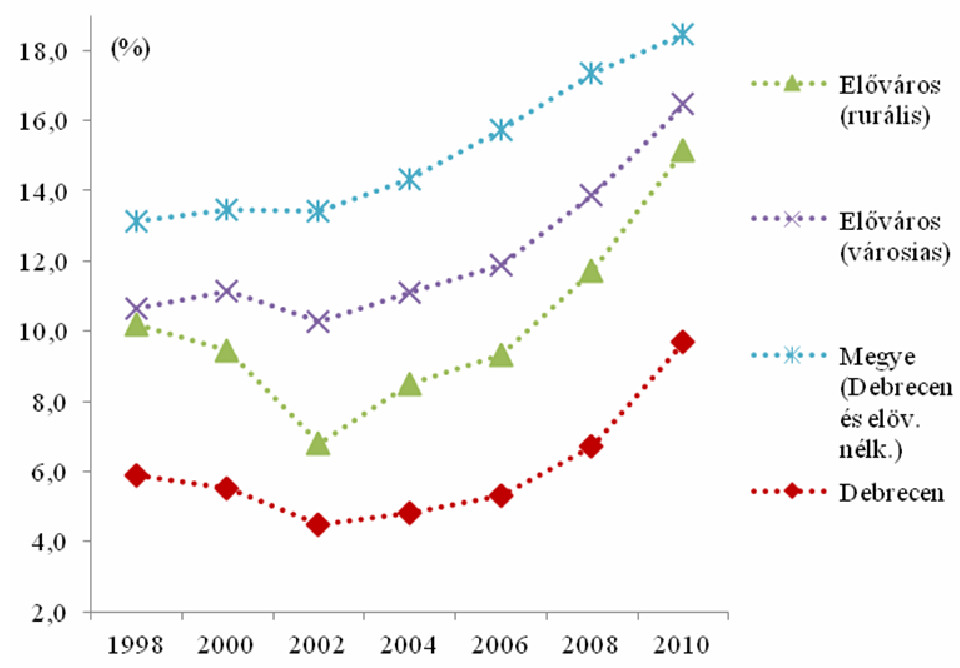

8. ábra. Munkanélküliségi ráta alakulása Hajdú-Bihar megyében. 1998-2010, (saját szerkesztés KSH, TeIR alapján). 
A munkanélküliségi rátát tekintve megállapítható, hogy annak értékei a vizsgált időszak végén a gazdasági világválságot megelőző időszakhoz képest jelentős emelkedést mutattak. A munkaerőpiaci helyzet romlása legkisebb mértékben az egyébként is magas munkanélküliséget elszenvedő elővároson kívüli térségben jelentkezett, ahol 2006 és 2010 között 2,4\%-kal növekedett a munkanélküliség. Ezt követte Debrecen, ahol ugyanebben az idöszakban a ráta 4,4\%-kal nőtt, míg a városias elővárosi térségben 4,6\%-os pozitív irányú változás következett be. A legrosszabb értékek a „rurális" elővárosi térségben mutathatók ki, itt a munkanélküliségi ráta a válság hatására 5,9\%-ot romlott ( 8 . ábra). A jövedelmi és munkaerőpiaci adatok együttesen a szuburbanizáció több jellegzetességére is rámutatnak. A jövedelmi adatok ,rurális” településeken tapasztalható emelkedéséből arra lehet következtetni, hogy a Debrecenből ezekre a területekre költözök többségében az aktív keresők közül kerültek ki. A válság hatására ebben a településkategóriában és Debrecenben legjelentősebben növekvő munkanélküliség azt a feltételezést támasztja alá, hogy a munkahelyek a kiköltözéseket kevésbé követték, többségükben a megyeszékhelyen maradtak. Ezt erősíti meg a munkanélküliségi adatok Debrecen és a megye többi része között megmutatkozó jelentős, 5-9\% közötti eltérése is.

\section{Regionális kínálati tényezők}

A megfigyelt folyamatok eredményeként településhatáron átnyúló többlet mobilitási igények generálódtak Debrecen és a közvetlen vonzáskörzetében található települések között. A többletigényeket kielégíteni hivatott regionális közösségi közlekedési kínálatot szabályozási szempontból három fontos peremfeltétel befolyásolja: a jogszabályi környezet, az ebböl eredő szervezeti struktúra és a regionális szintü szolgáltatások finanszírozási feltételei. Ezek alakulását a vizsgált közel 20 éves időszakban Magyarország európai uniós integrációja és a gazdaság teljesítőképessége a regionális folyamatok mentén megjelenő utazási igényeknél jelentősebb mértékben befolyásolta. Megállapítható, hogy a magyarországi közlekedésszervezés vizsgált időszakának máig meghatározó szabályozási, finanszírozási és szervezeti jellemzöje a helyközi és a helyi közösségi közlekedés ellátásért felelős megrendelői és üzemeltetői szintjének éles elkülönülése (9. ábra). 


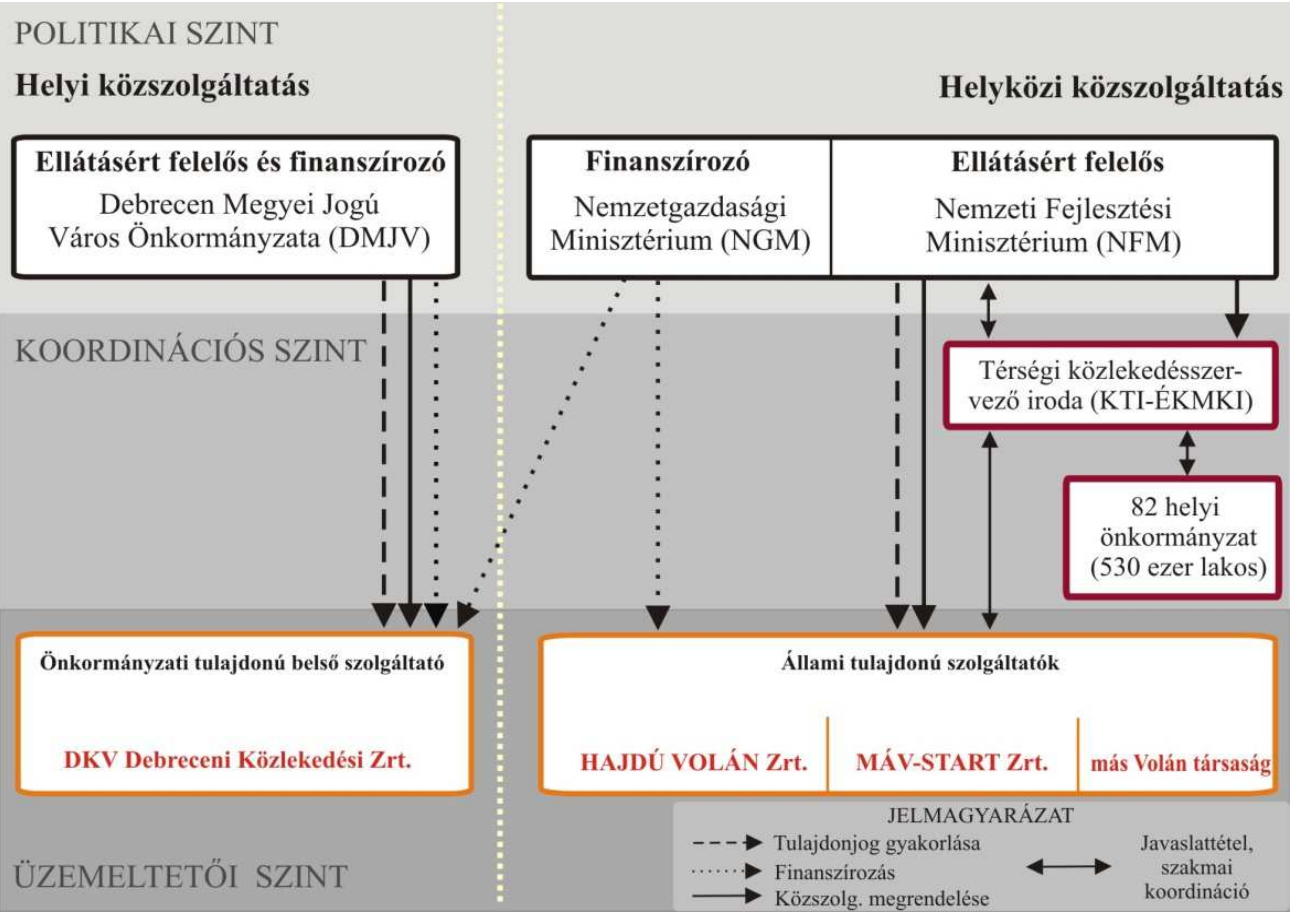

9. ábra. Hajdú-Bihar megye közösségi közlekedésszervezésének sematikus ábrája (saját szerkesztés).

A helyközi menetrendszerinti személyszállítás megszervezése alapvetően kötelezö állami, a helyi menetrendszerinti személyszállitásé pedig önként vállalt helyi önkormányzati feladat. A finanszírozás túlnyomó része a központi költségvetés forrásaiból közvetlenül, vagy az önkormányzatok számára onnan átadott forrásokból közvetve történik. A naponta ingázók helyváltoztatása által behatárolt városkörnyéki terek, agglomerációk, netán régiók közösségi közlekedésszervezési kérdéseinek egységes szemléletű kezelésére hivatott ellátásért felelős megrendelői szervezet a gyakorlatban sem Hajdú-Bihar megyében, sem pedig Magyarországon nem jött létre. A regionális közösségi közlekedés alakításában a helyközi szolgáltatásokat megrendelő Nemzeti Fejlesztési Minisztérium megbízásából a KTI Nonprofit Kft. szervezetén belül tevékenykedő térségi közlekedésszervező irodák koordinációs szereppel bírnak.

A közösségi közlekedés infrastruktúra hálózatát a közforgalmú személyszállítás szempontjából megvizsgálva változatos képet kapunk. A KSH 2011. évi adatai alapján a megye területéhez viszonyított vasúti hálózatsürüsége az országos átlagnál és az Észak-Alföldi régió átlagánál is alacsonyabb. A közúti hálózatsürüség az országos átlagtól jelentősen, a régiós átlagtól pedig kis mértékben marad el. A vasúti hálózatracionalizálás és a megyét érintő nagyobb volumenü útépítések által meghatározott 2005 és 2011 közötti időszak változásait megvizsgálva tovább árnyalható a kép. Hajdú-Bihar megye közúthálózata az országos és regionális átlagnál - részben a megyét érintő autópálya fejlesztések hatására - jobban fejlődött. Ezzel szemben a vasúti személyszállítás hálózatának hajdú-bihari megrövidítése - a 
2007-es és 2009-es üzemszünetek hatására - mind az országos, mind pedig a regionális mértéket meghaladta. Mindezek alapján a megye infrastruktúrahálózata hazai viszonylatban összességében az átlagosnál rosszabbnak mondható a közúti elemek relatíve dinamikusabb fejlődése mellett.

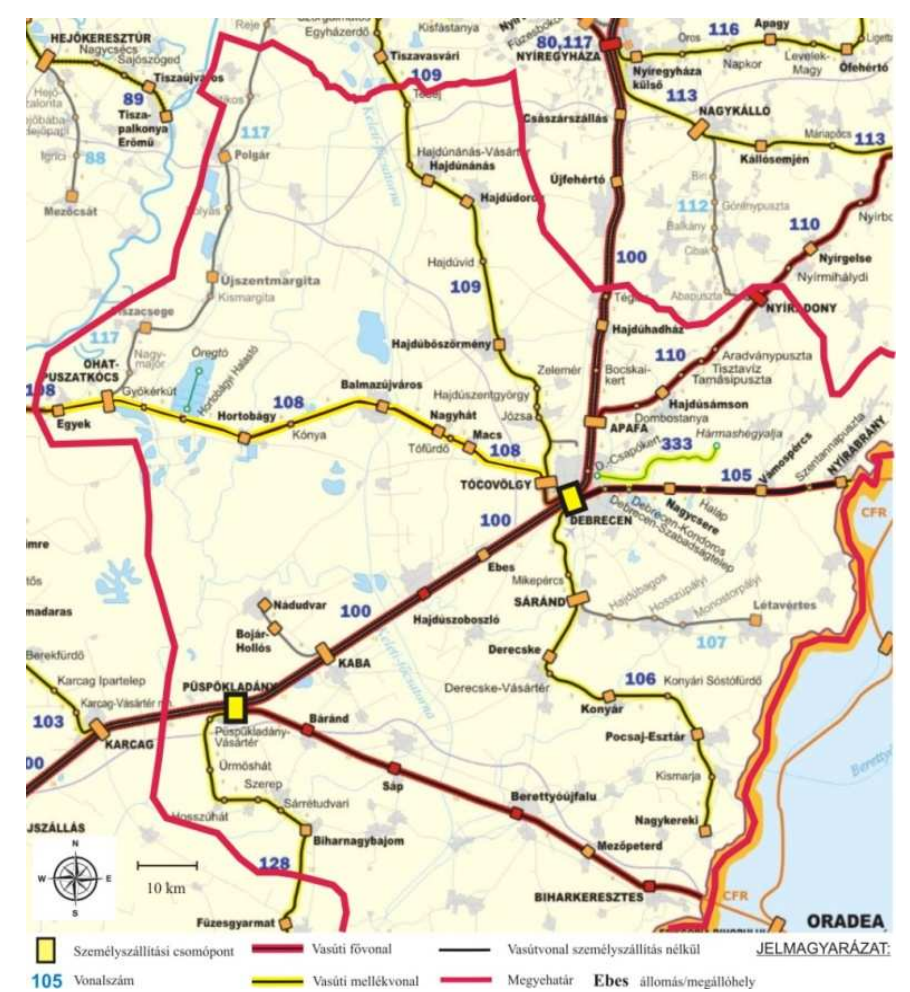

10. ábra. Hajdú-Bihar megye vasúthálózata 2014-ben (saját szerkesztés). ${ }^{6}$

A megye személyszállításban is érintett vasúthálózata 9 vasútvonalból áll (10. ábra), ezek megyén belüli szakaszának hossza $406 \mathrm{~km}$. Ebböl $147 \mathrm{~km}$ vasúti fővonal, amelynek kevesebb, mint fele $(66 \mathrm{~km})$ kétvágányú villamosított szakasz. A fennmaradó fővonali rész és a 259 km-es mellékvonali pályahálózat egyvágányú, kiszolgálása dízelvontatással történik. A MÁV-START Zrt. 1994 és 2013 közötti menetrendi adatai alapján a 82 hajdú-bihari település közül 33 érhető el vasúton. A településeket érintő megállóhelyek száma a vizsgált időszakban csökkent: míg 1994ben a megyei vasúthálózaton 81, addig 2013-ban már csak 62 megállóhely volt.

Mindezt egyes vasútvonalak személyszállításának szüneteltetése mellett a kis forgalmú vasúti megállóhelyek megszüntetése okozta. A vasúti megállóhelyek átlagos rágyaloglási távolsága a településközpontoktól jelentős: 2013-ben saját számításaim szerint meghaladta az 1,3 km-t. A vizsgált időszakban több mint 40\%kal, 232-re növekedett a munkanapon indított vonatok száma, ennek jelentős részét a vasúti fővonalakon 2007-ben bevezetett ütemes menetrend szerint közlekedő

\footnotetext{
${ }^{6}$ Alaptérkép forrása: https://sites.google.com/site/ballalaszlo/elso (a letöltés ideje 2013. 09. 15.).
} 
távolsági vonatok teszik ki. A vasúti hálózat erősen centrális jellegü, a Debrecent elkerülő átlós kapcsolatok teljesen hiányoznak, a megyeszékhelyet csak két (a 101. számú Püspökladány-Biharkeresztes és a 128. számú Püspökladány-Vésztő) vonal nem érinti. Mindebből következik, hogy a régió többi megyéjétől eltérően HajdúBihar megyében a megyeszékhelyen kívül csak egy - viszonylag alacsony utasforgalmú - személyszállítási csomópont található Püspökladányban.

Autóbusszal a megye összes települése megközelíthetö, az autóbusz hálózatnak minden település központjában található megállóhelye. Az autóbuszos közszolgáltatás hálózata a megye területén öt országos, 84 regionális, valamint két országos és regionális járatokat egyaránt tartalmazó vonalból áll. ${ }^{7}$ Az autóbuszos vonalhálózat a vasútinál jelentősen nagyobb hálózati lefedettséget biztosít: hossza 1439 km, amely a megye teljes közúthálózatának 86\%-a. A megállóhelyek és az indított járatok vonatkozásában 2002 és 2013 között rendelkezésre álló menetrendi adatok alapján a megye autóbusz megállóhelyeinek száma a vizsgált időszakban 7,6\%-os növekedést mutatva 2013-ban 1144 volt. Ennél is jelentősebben 35,4\%-kal növekedett az átlagos munkanapon indított járatok darabszáma, amely így 1682-ot tett ki a 2013-ban érvényes közforgalmú menetrend szerint. A megye autóbuszközlekedés által használt úthálózatát és az indított járatok számát egyaránt tartalmazó járatintenzitási térkép alapján kitünik, hogy az autóbuszos hálózat szintén Debrecen központú, de itt már megjelentek az átlós, megyeszékhelyet megkerülő vonalak is (11. ábra).

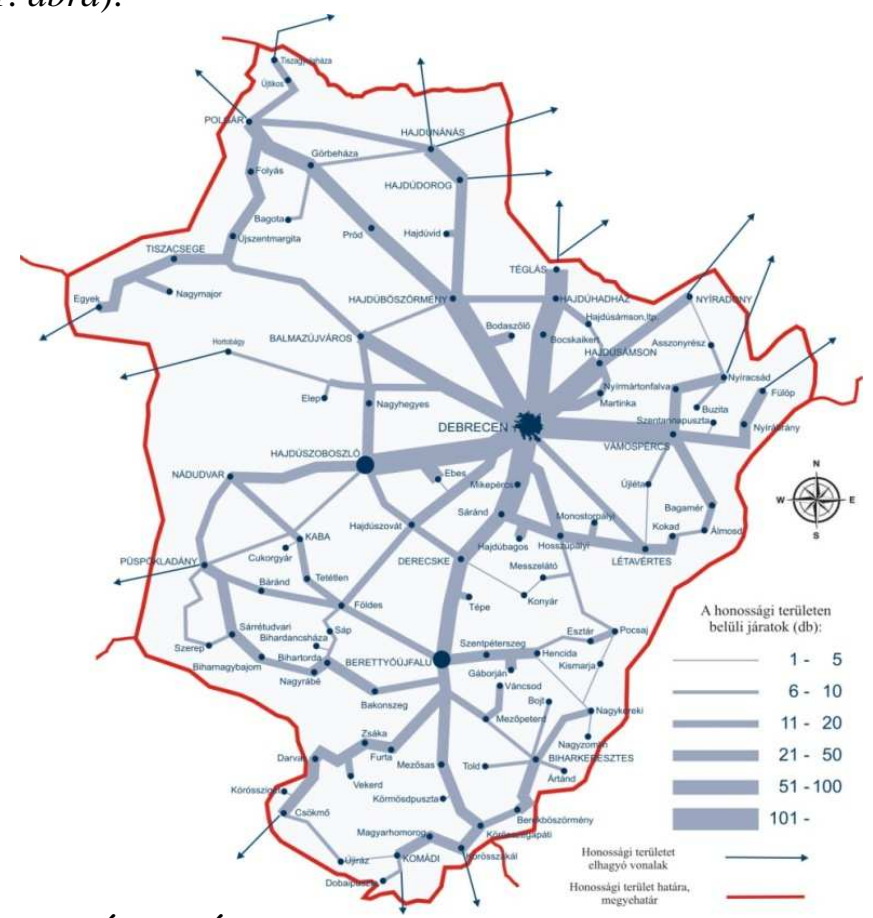

11. ábra. A HAJDÚ VOLÁN Zrt. járatintenzitási térképe, 2013 (saját szerkesztés a HAJDÚ VOLÁN Zrt. térképe alapján).

\footnotetext{
${ }^{7}$ HAJdÚ VolÁN ZRT.: Tájékoztató a megye közúti közlekedési helyzetéről (Készült a HajdúBihar Megyei Közgyülés 2013. szeptember 27-i ülésére), Debrecen. 2013.
} 
Az átlós vonalak járatainak száma azonban - a jelentkező utazási igényeknek megfelelően - alulmúlja a megyeszékhelyre irányuló járatintenzitást. A közúti közösségi közlekedési hálózatnak Debrecenen kívül több csomópontja is van, amelyek közül legjelentősebbek az autóbusz állomással is rendelkező Berettyóújfalu és Hajdúszoboszló. A közösségi közlekedési módok hálózatsürüsége, megállóhely ellátottsága és infrastrukturális jellemzői alapján megállapítható, hogy a megye településein élők többsége számára a közúti közlekedési ágazat paraméterei előnyösebbek. Ezen a tényen a térségben elérhető közösségi közlekedési infrastruktúra- és szolgáltatásfejlesztési célú uniós források sem változtattak lényeges mértékben (12. ábra).

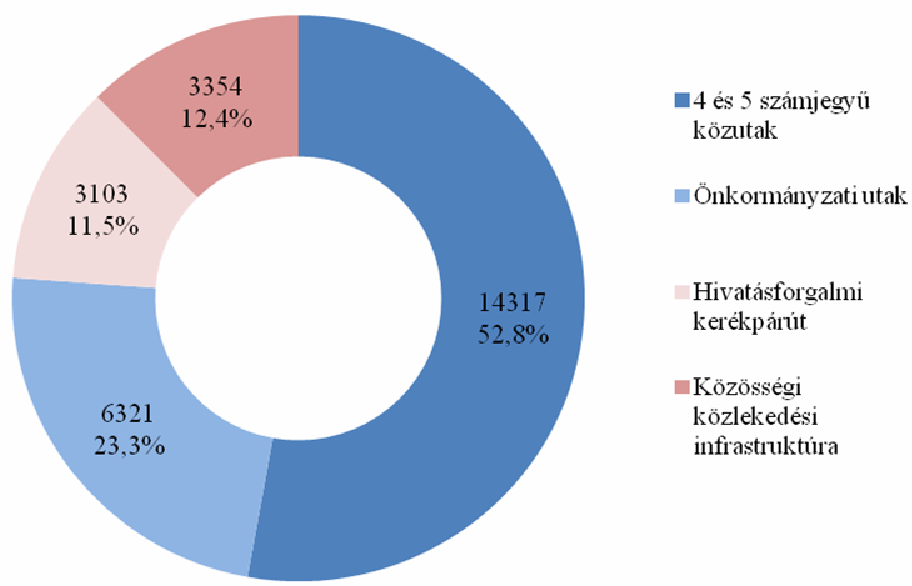

11. ábra. Az ÉAOP közlekedésfejlesztési célokra megítélt támogatásai (M. Ft.), 20072013, az NFÜ Jelentéskészítő és Lekérdező Keretrendszere 2013. 09. 30-i adatai alapján.

Amíg a megítélt támogatások túlnyomó része a közúti és a kerékpárút hálózat fejlesztését szolgálta, a közösségi közlekedés fejlesztésére a forrásoknak csak alig több mint egytizede jutott. A támogatott projektek az Észak-Alföldi Operatív Programon (ÉAOP) belül szinte kizárólag a közúti ágazatban találhatók, a regionális felhasználású forrásokból csak az érintett tervezési időszak végén és korlátozottan volt lehetőség a megye vasúti infrastruktúráját javító projektek finanszírozására. A források jelentősége így sem elhanyagolható, mivel számos olyan projekt valósult meg segítségükkel, amely a közösségi közlekedés minőségi feltételeit jelentősen javította. Ilyen volt például - az utaskiszolgáló létesítmények több térségben megvalósított fejlesztése mellett - a HAJDÚ VOLÁN Zrt. és a DKV Zrt. korszerü utastájékozató és forgalomszervezési rendszerének kiépítése. A 106-os számú vasútvonal mentén élők eljutási lehetőségeire minden bizonnyal pozitív hatása lesz a térség egyetlen megvalósulás alatt álló vasúti és autóbuszos szolgáltatásokat egyaránt érintő komplex fejlesztésének - az „Értől az Óceánig” projektnek.

A Közlekedés Operatív Program (KÖZOP) Hajdú-Bihar megyére jutó 208 milliárdos forrásánál ettől eltérő a helyzet: a támogatás 75,7\%-a jutott vasútfejlesztésre; 8,8\%-a városi, elővárosi kötöttpályás közlekedés fejlesztésére és 
15,5\%-a közútfejlesztésre. Mivel a vasúti projektekre megítélt összeg szinte kizárólag a 100-as számú vasúti fővonal rekonstrukcióját szolgálja, a beruházás hatásai a regionális és elővárosi kötöttpályás hálózatra várhatóan csak áttételesen érvényesülnek majd. A városi és elővárosi fejlesztéseket támogató összeg a megyében a Debreceni 2-es városi villamosvonal megvalósulását célozta.

A szolgáltatási jellemzők értékelése - húsz évre visszatekintve - az 1993/94., a 2000/2001., valamint a 2012/2013. évi autóbuszos és vasúti közforgalmú menetrend alapján három mutatószám mentén történt. Tekintettel arra, hogy az elemzés célja elsősorban a közösségi közlekedési kínálat és a szuburbanizáció migrációs hatásai közötti összefüggések vizsgálata volt, a legfontosabb mennyiségi mutató a munkanapokon indított járatok számának 1000 lakosra vetített aránya. Ezt kiegészítve a munkanapi üzemidö alakulása elsősorban a térségben alkalmazott munkarend és a lakossági időfelhasználás változásaira adott válaszok bemutatására alkalmas. A menetidő időbeli alakulása pedig az infrastrukturális adottságok és a közúti szegmens esetén a közutak zsúfoltsága tekintetében egyaránt szolgáltathat információkat. Az elemzés célja nem egyes települések ellátottságának jellemzése volt, hanem az ellátási paraméterek változásának szegmensenkénti és időbeli összehasonlító elemzése, így a más szerzők által kidolgozott összetett mutatók alkalmazását itt nem tartottam célszerünek. ${ }^{8}$

Az egyes települések közlekedési szolgáltatási jellemzőinek változását az 1. és 2. táblázat elsősorban tendenciájában mutatja be, a számszerü adatok az 1 . mellékletben találhatók.

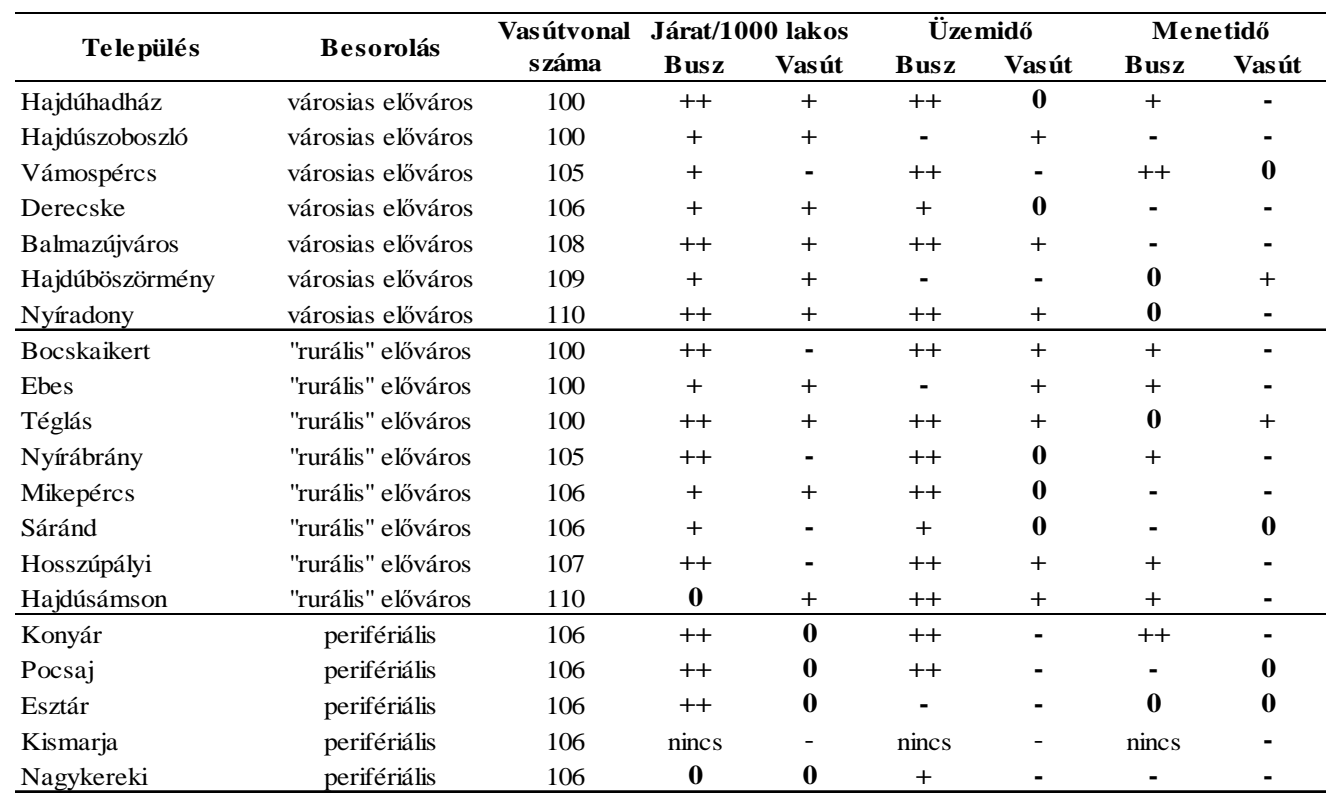

1. táblázat. A vizsgált települések ellátási jellemzőinek változása 2001/1994 (--: jelentősen romlott, -: romlott, 0: változatlan, +: javult, ++: jelentősen javult). ${ }^{9}$

${ }^{8}$ BAJMÓCY: i. m., 30-45.

${ }^{9}$ A MÁV Rt. és a HAJDÚ VOLÁN Rt. menetrendjei alapján saját számítás és szerkesztés. 
Az 1. táblázatból jól látható, hogy Debrecenből Kismarján kívül az összes település egyaránt megközelíthető autóbuszon és vasúton is. A szolgáltatás szempontjából vizsgált időszak első szakaszában, amikor a megyeszékhelyről való kiköltözés a környező „rurális” településekre erőteljesen, a városias térségekbe korlátozottabban volt jellemzö, az autóbusz közlekedés paraméterei követték jobban a migrációs változásokat. Az eljutási lehetőségek száma minden településkategóriában a népességbővülést meghaladó mértékben növekedett, vagy legalább szinten maradt (pl. Hajdúsámson esetében). A kínálat jelentős bővülése leginkább a kiköltözők számára fontos céltelepülések esetén volt tetten érhető (Téglás, Bocskaikert, Nyírábrány, Hosszúpályi). A közúti szolgáltatás mennyiségi paraméterei a 106. számú vonal mentén fekvő korábban szinte csak vasúton kiszolgált perifériális települések esetén is javultak, de a Debrecen közelében lévő települések számára biztosított szintet nem érték el.

Az üzemidő szinte minden település esetén növekedett, a szórványos üzemidő csökkenést a Debrecenben müködő nagyüzemek bezárását követően feleslegessé váló müszakos járatok megszüntetése magyarázza. Bár az autóbuszos menetidő több település esetén is romlott, a kiköltözések által intenzíven érintett települések esetében javulás történt. Mindez a nagyobb megállóhely sürüséggel és a kisebb rágyaloglási távolsággal kiegészülve a vasúthoz képest versenyképes eljutási időt biztosított.

A vasúti kapcsolatok mennyisége ezzel szemben föleg a kiköltözések által kevésbé érintett városok esetén javult, a fontos alvótelepüléssé vált, korábbi vidékies településeknél (Bocskaikert, Hajdúsámson, Nyírábrány) pedig romlott. Az üzemidő általában jól követte a munkaerőpiac változásait, a korábban távolabbról is nagy tömegben a nagyüzemekbe bejáró munkaerő elbocsátásának megfelelően a perifériális települések esetében lerövidült, a többi településtípus esetén azonban többnyire javult, vagy szinten maradt. A menetidő az infrastrukturális állapotokra való tekintettel szinte minden település esetében romlott. 


\begin{tabular}{|c|c|c|c|c|c|c|c|c|}
\hline \multirow{2}{*}{ Település } & \multirow{2}{*}{ Besorolás } & \multirow{2}{*}{$\begin{array}{c}\text { Vasútvonal } \\
\text { száma }\end{array}$} & \multicolumn{2}{|c|}{ Járat/1000 lakos } & \multicolumn{2}{|c|}{ Üzemidő } & \multicolumn{2}{|c|}{ Menetidő } \\
\hline & & & Busz & Vasút & Busz & Vasút & Busz & Vasút \\
\hline Hajdúszoboszló & városias előváros & 100 & $\mathbf{0}$ & + & + & + & - & + \\
\hline Vámospércs & városias előváros & 105 & + & + & $\mathbf{0}$ & - & + & + \\
\hline Derecske & városias előváros & 106 & + & + & $\mathbf{0}$ & $\mathbf{0}$ & + & + \\
\hline Balmazújváros & városias előváros & 108 & ++ & + & + & - & ++ & + \\
\hline Hajdúböszörmény & városias előváros & 109 & $\mathbf{0}$ & $\mathbf{0}$ & - & - & $\mathbf{0}$ & - \\
\hline Nyíradony & városias előváros & 110 & + & + & $\mathbf{0}$ & - & + & $\mathbf{0}$ \\
\hline Bocskaikert & "rurális" előváros & 100 & + & + & $\mathbf{0}$ & + & $\mathbf{0}$ & + \\
\hline Ebes & "rurális" előváros & 100 & + & + & + & + & $\mathbf{0}$ & + \\
\hline Téglás & "rurális" előváros & 100 & ++ & + & $\mathbf{0}$ & + & $\mathbf{0}$ & $\mathbf{0}$ \\
\hline Nyírábrány & "rurális" előváros & 105 & + & + & - & - & ++ & 0 \\
\hline Mikepércs & "rurális" előváros & 106 & - & megszünt & $\mathbf{0}$ & megszünt & + & megszünt \\
\hline Sáránd & "rurális" előváros & 106 & + & - & $\mathbf{0}$ & - & + & - \\
\hline Hosszúpályi & "rurális" előváros & 107 & ++ & megszünt & + & megszünt & - & megszünt \\
\hline Hajdúsámson & "rurális" előváros & 110 & - & - & $\mathbf{0}$ & - & $\mathbf{0}$ & + \\
\hline Konyár & perifériális & 106 & + & + & + & $\mathbf{0}$ & + & + \\
\hline Pocsaj & perifériális & 106 & $\mathbf{0}$ & + & + & $\mathbf{0}$ & ++ & $\mathbf{0}$ \\
\hline Esztár & perifériális & 106 & + & + & ++ & $\mathbf{0}$ & + & $\mathbf{0}$ \\
\hline Kismarja & perifériális & 106 & nincs & + & nincs & $\mathbf{0}$ & nincs & + \\
\hline Nagykereki & perifériális & 106 & + & + & + & $\mathbf{0}$ & - & + \\
\hline
\end{tabular}

2. táblázat. A vizsgált települések ellátási jellemzőinek változása 2013/2001 (--: jelentősen romlott, -: romlott, 0: változatlan, +: javult, ++ : jelentősen javult). ${ }^{10}$

A menetrendi szempontból elemzett időszak második szakaszában az alágazati munkamegosztás a vizsgált viszonylatokon annyiban változott, hogy az elővárosi Mikepércs és Hosszúpályi vasúti kiszolgálása megszünt. Az autóbusz közlekedés kínálatának bővülése a legtöbb település esetén ebben az időszakban is meghaladta a népesség növekedését a legjelentősebb vonzó hatással bíró két település - Mikepércs és Hajdúsámson - esetén azonban ez már nem volt igaz (2. táblázat).

Folytatódott az előző időszakban megfigyelt tendencia: tovább bővültek az autóbuszos eljutási lehetőségek a vasúttal egyébként jól ellátott elővárosi települések (Téglás, Bocskaikert, Balmazújváros) és a Debrecentől távolabb fekvő települések (Konyár, Pocsaj, Esztár) esetében is, ez utóbbiaknál különösen az üzemidő tekintetében. Fontos megjegyezni, hogy az autóbuszos menetidőt majdnem minden település esetén sikerült szinten tartani, vagy javítani, növelve ezzel a szolgáltatás színvonalát.

A vasúti kínálat majd minden települést érintő bővülése a 2007-ben bevezetett ütemes menetrendnek volt köszönhető. Ez alól csak a 107. számú vasútvonal 2009es személyszállítási üzemszünetében és a 106. vonal megállóhely racionalizálásában érintett települések (Sáránd, Hosszúpályi és Mikepércs) jelentettek kivételt. Az ütemes menetrend bevezetésének és további menetrendi beavatkozásoknak köszönhetően kis mértékben javult a menetidő is, annak ellenére, hogy a vasúti pálya adottságai - föleg a mellékvonalakon - tovább romlottak. A munkaerő piaci változások, valamint a müszakos munkarendben dolgozók számának további csökkenése, autóbuszos kiszolgálásuk javulása következtében az elővárosi

\footnotetext{
${ }^{10}$ A MÁV-START Zrt. és a HAJDÚ VOLÁN Zrt. menetrendjei alapján saját számítás és szerkesztés.
} 
települések elérésének vasúti üzemideje - a 100-as vonal mentén fekvő települések kivételével - mindenhol csökkent, a perifériális besorolású települések esetében pedig változatlan maradt. Az egyes ágazatok által biztosított mennyiségi paraméterek időbeli alakulását összefoglalóan a 12. ábra mutatja.

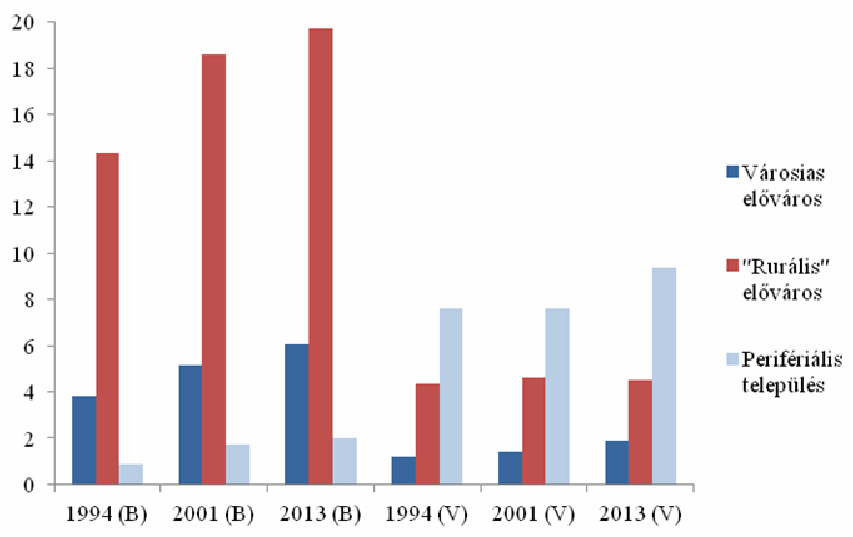

12. ábra. Autóbuszos (A) és vasúti (V) ellátottság alakulása településkategóriánként (járat/1000 lakos). ${ }^{11}$

Az autóbusz közlekedés kínálata a kiköltözések által leginkább érintett „rurális” kategóriába sorolt települések esetében fejlődött leginkább, annak időbeli intenzitásváltozását is lekövetve. A térség vasúti kiszolgálásában ehhez képest - a szuburbanizációs folyamatokat részben figyelmen kívül hagyva - a városias besorolású, illetve perifériális települések esetén történtek menetrendi fejlesztések. Mindezt, illetve a közúti közösségi közlekedés térnyerését az elővárosi viszonylatokban mért hivatásforgalmi utasszámok is visszatükrözik, a közúti ágazat vasúthoz képest kiemelkedő elővárosi utasforgalmát mutatva (13. ábra).

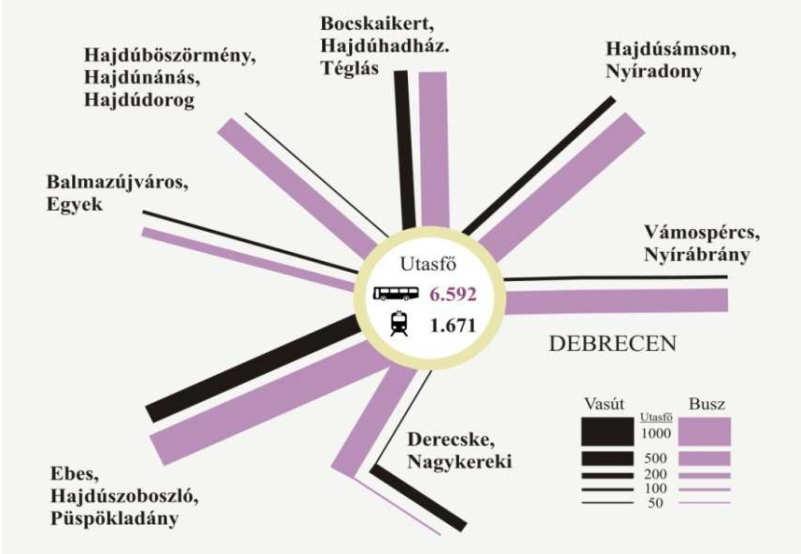

13. ábra. Debrecen, autóbusz állomás és Debrecen Nagyállomás kiválasztott irányonkénti, munkanapi átlagos utasforgalma 13:00 és 17:00 között. ${ }^{12}$

\footnotetext{
${ }^{11}$ A MÁV-START Zrt. és a HAJDÚ VOLÁN Zrt. menetrendjei alapján saját számítás és szerkesztés.
} 


\section{Konklúziók}

A szuburbanizációra jellemző regionális mobilitási folyamatok Debrecen elővárosi térségében is tetten érhetők, de elsősorban a Debrecen környéki - vonzásközponti funkcióval nem rendelkező - települések és a megyeszékhely viszonylatában voltak jelentősek a vizsgált időszakban. A többletként megjelenő utazási igényeket Debrecen elővárosában a rugalmasabban alakítható szolgáltatási paraméterekkel és megyei szintủ szervezettel rendelkező közúti szolgáltató kínálata elégíti ki nagyobb mértékben. Ugyanakkor megállapítható, hogy az elemzett adatok alapján mind a vasúti, mind pedig az autóbuszos menetrendi kínálat jelentősen növekedett, sokszor azonos viszonylatok esetében is. Az autóbuszos közszolgáltatások helyzetét erősítette, hogy a 2007-2013 közötti időszak fejlesztési lehetőségeiben a közúti infrastruktúra prioritásai voltak jellemzők, így a közúti és vasúti hálózati jellemzők közötti különbség nem csökkent.

A közösségi közlekedés szerepe a térség regionális hivatásforgalmában - különösen a szomszédos országokkal összehasonlítva - összességében meghatározó maradt. Ezen szerep megtartása érdekében azonban a jövőben a szolgáltatási minőséget fejlesztő beavatkozások szükségesek. Mindehhez azonban a fejlesztésekre és a szolgáltatás megrendelésére vonatkozó állami szabályozás kereteinek átalakítása és a közszolgáltatásokra fordított közpénzek hatékonyabb felhasználását figyelembe vevő alágazati prioritásokra vonatkozó irányelvek meghatározása megkerülhetetlen. Erre épülve kerülhet sor - a hálózati adottságok és a felmerülő mobilitási igények további részletes vizsgálata, valamint az eltérő alágazati beruházási és üzemeltetési költségekre kiterjedő gazdaságossági számítások elvégzése alapján - a Debrecen elővárosi térségében alkalmazandó minőségközpontú, integrált szolgáltatási modell kialakítására.

\footnotetext{
${ }^{12} 2013$ januárjában végzett saját utasszámlálás és a KTI adatai alapján saját szerkesztés.
} 


\section{Mellékletek}

\section{A közösségi közlekedés részletes szolgáltatási jellemzői a kiválasztott településeken. ${ }^{13}$}

\begin{tabular}{|c|c|c|c|c|c|c|c|}
\hline \multirow{3}{*}{ Település } & \multirow{3}{*}{ Besorolás } & \multicolumn{6}{|c|}{$1993 / 1994$} \\
\hline & & \multicolumn{2}{|c|}{ Járat/1000 lakos } & \multicolumn{2}{|c|}{ Üzemidő (perc) } & \multicolumn{2}{|c|}{ Átl. menetidó (perc) } \\
\hline & & Busz & Vasút & Busz & Vasút & Busz & Vasút \\
\hline Hajdúhadház & városias előváros & 2,6 & 2,4 & 1040 & 1081 & 39,5 & 18 \\
\hline Hajdúszoboszló & városias előváros & 3,1 & 1,8 & 1225 & 1073 & 23,5 & 14 \\
\hline Vámospércs & városias előváros & 15,5 & 2,8 & 1083 & 1113 & 62 & 26 \\
\hline Derecske & városias előváros & 10,7 & 1,5 & 1095 & 1107 & 32,5 & 34 \\
\hline Balmazújváros & városias előváros & 1,2 & 0,9 & 1080 & 1085 & 47,5 & 30,5 \\
\hline Hajdúböszörmény & városias előváros & 3,3 & 0,4 & 1380 & 1110 & 29 & 34,5 \\
\hline Nyíradony & városias előváros & 2,3 & 2,3 & 1080 & 1098 & 52 & 36,5 \\
\hline Bocskaikert & "rurális" előváros & 19,5 & 14,0 & 1033 & 1063 & 29,5 & 14 \\
\hline Ebes & "rurális" előváros & 17,7 & 5,3 & 1217 & 1066 & 16 & 9,5 \\
\hline Téglás & "rurális" előváros & 1,5 & 4,3 & 826 & 1071 & 35,5 & 25 \\
\hline Nyírábrány & "rurális" előváros & 1,8 & 3,9 & 729 & 1133 & 78 & 34 \\
\hline Mikepércs & "rurális" előváros & 42,1 & 3,7 & 1076 & 1082 & 17 & 15 \\
\hline Sáránd & "rurális" előváros & 45,5 & 10,3 & 1084 & 1108 & 22,5 & 19 \\
\hline Hosszúpályi & "rurális" elóváros & 6,9 & 2,8 & 965 & 1101 & 33,5 & 33 \\
\hline Hajdúsámson & "rurális" előváros & 12,4 & 2,1 & 1085 & 1077 & 42 & 19 \\
\hline Konyár & perifériális & 0,0 & 6,2 & 0 & 1130 & 0 & 45 \\
\hline Pocsaj & perifériális & 1,4 & 5,1 & 635 & 1160 & 69 & 59,5 \\
\hline Esztár & perifériális & 1,4 & 9,6 & 635 & 1160 & 69 & 59,5 \\
\hline Kismarja & perifériális & 0,0 & 10,3 & 0 & 1175 & 0 & 66,5 \\
\hline Nagykereki & perifériális & 1,5 & 10,2 & 338 & 1190 & 90 & 73 \\
\hline
\end{tabular}

\footnotetext{
${ }^{13}$ A MÁV-START Zrt. és a HAJDÚ VOLÁN Zrt. menetrendjei alapján saját számítás és szerkesztés.
} 


\begin{tabular}{|c|c|c|c|c|c|c|c|}
\hline \multirow{3}{*}{ Település } & \multirow{3}{*}{ Besorolás } & \multicolumn{6}{|c|}{$2000 / 2001$} \\
\hline & & \multicolumn{2}{|c|}{ Járat/1000 lakos } & \multicolumn{2}{|c|}{ Üzemidő (perc) } & \multicolumn{2}{|c|}{ Menetidő (perc) } \\
\hline & & Busz & Vasút & Busz & Vasút & Busz & Vasút \\
\hline Hajdúhadház & városias előváros & 5,2 & 2,6 & 1109 & 1082 & 31 & 21,5 \\
\hline Hajdúszoboszló & városias előváros & 4,5 & 2,2 & 1108 & 1089 & 26,5 & 15,5 \\
\hline Vámospércs & városias előváros & 17,2 & 2,5 & 1118 & 1095 & 33,5 & 31 \\
\hline Derecske & városias előváros & 11,3 & 1,6 & 1131 & 1102 & 35 & 35,5 \\
\hline Balmazújváros & városias előváros & 2,3 & 1,1 & 1133 & 1120 & 51,5 & 36 \\
\hline Hajdúböszörmény & városias előváros & 4,6 & 0,6 & 1358 & 1017 & 28,5 & 30,5 \\
\hline Nyíradony & városias előváros & 4,1 & 2,7 & 1145 & 1116 & 54,5 & 39 \\
\hline Bocskaikert & "rurális" előváros & 29,3 & 12,6 & 1095 & 1079 & 24,5 & 15,5 \\
\hline Ebes & "rurális" előváros & 23,9 & 6,3 & 1087 & 1096 & 14 & 10 \\
\hline Téglás & "rurális" előváros & 9,8 & 5,6 & 1125 & 1086 & 37 & 23 \\
\hline Nyírábrány & "rurális" előváros & 3,7 & 3,5 & 1153 & 1113 & 72 & 27,5 \\
\hline Mikepércs & "rurális" előváros & 43,9 & 4,0 & 1101 & 1086 & 21 & 16,5 \\
\hline Sáránd & "rurális" előváros & 54,9 & 9,3 & 1106 & 1110 & 24,5 & 18,5 \\
\hline Hosszúpályi & "rurális" előváros & 9,7 & 2,7 & 1126 & 1117 & 31 & 36 \\
\hline Hajdúsámson & "rurális" előváros & 12,8 & 2,1 & 1127 & 1093 & 31,5 & 26 \\
\hline Konyár & perifériális & 0,9 & 6,4 & 433 & 1117 & 55 & 52 \\
\hline Pocsaj & perifériális & 2,9 & 5,1 & 714 & 1134 & 74,5 & 61,5 \\
\hline Esztár & perifériális & 2,8 & 9,8 & 522 & 1134 & 67,5 & 61,5 \\
\hline Kismarja & perifériális & 0,0 & 9,9 & 0 & 1142 & 0 & 71,5 \\
\hline Nagykereki & perifériális & 1,5 & 10,2 & 434 & 1150 & 97 & 82 \\
\hline
\end{tabular}

\begin{tabular}{|c|c|c|c|c|c|c|c|}
\hline \multicolumn{8}{|c|}{$2012 / 13$} \\
\hline \multirow{2}{*}{ Település } & \multirow{2}{*}{ Besorolás } & \multicolumn{2}{|c|}{ Járat/1000 lakos } & \multicolumn{2}{|c|}{ Üzemidő (perc) } & \multicolumn{2}{|c|}{ Menetidő (perc) } \\
\hline & & Busz & Vasút & Busz & Vasút & Busz & Vasút \\
\hline Hajdúhadház & városias előváros & 8,5 & 3,6 & 1107 & 1093 & 29 & 18,5 \\
\hline Hajdúszoboszló & városias előváros & 4,8 & 3,4 & 1125 & 1199 & 28,5 & 14 \\
\hline Vámospércs & városias előváros & 18,0 & 3,2 & 1111 & 875 & 29,5 & 24 \\
\hline Derecske & városias előváros & 13,1 & 1,9 & 1120 & 1105 & 30,5 & 33 \\
\hline Balmazújváros & városias előváros & 3,6 & 1,4 & 1120 & 1092 & 37 & 32,5 \\
\hline Hajdúböszörmény & városias előváros & 4,8 & 0,7 & 1200 & 1003 & 29 & 31,5 \\
\hline Nyíradony & városias előváros & 5,0 & 3,3 & 1146 & 1021 & 50,5 & 39 \\
\hline Bocskaikert & "rurális" előváros & 35,8 & 15,0 & 1090 & 1098 & 23,5 & 13,5 \\
\hline Ebes & "rurális" előváros & 25,4 & 10,5 & 1095 & 1205 & 14,5 & 9 \\
\hline Téglás & "rurális" előváros & 15,7 & 7,2 & 1125 & 1095 & 36,5 & 22,5 \\
\hline Nyírábrány & "rurális" előváros & 5,3 & 4,5 & 1144 & 891 & 44 & 39 \\
\hline Mikepércs & "rurális" előváros & 36,8 & 0,0 & 1106 & 0 & 19,5 & 0 \\
\hline Sáránd & "rurális" előváros & 59,9 & 7,1 & 1115 & 1095 & 20,5 & 21,5 \\
\hline Hosszúpályi & "rurális" előváros & 12,3 & 0,0 & 1150 & 0 & 38 & 0 \\
\hline Hajdúsámson & "rurális" előváros & 10,6 & 1,8 & 1125 & 1001 & 32 & 23,5 \\
\hline Konyár & perifériális & 1,3 & 7,5 & 601 & 1118 & 53 & 44,5 \\
\hline Pocsaj & perifériális & 2,9 & 6,2 & 728 & 1135 & 65 & 61,5 \\
\hline Esztár & perifériális & 3,5 & 12,0 & 710 & 1135 & 63,5 & 61,5 \\
\hline Kismarja & perifériális & 0,0 & 12,6 & 0 & 1143 & 0 & 69,5 \\
\hline Nagykereki & perifériális & 1,5 & 13,1 & 452 & 1153 & 106 & 78,5 \\
\hline
\end{tabular}

